\title{
Experimental and theoretical investigation of the structure and nucleophilic properties of 4-aminocoumarin
}

\author{
Bistra Stamboliyska, ${ }^{a}$ Voislava Janevska, ${ }^{b}$ Boris Shivachev, ${ }^{c}$ Rosica P. Nikolova, ${ }^{\text {c }}$ \\ Goran Stojkovic, ${ }^{b}$ Bozhna Mikhova, ${ }^{a}$ and Emil Popovski ${ }^{b^{*}}$ \\ ${ }^{a}$ Institute of Organic Chemistry with Centre of Phytochemistry, Bulgarian Academy of Sciences, \\ Acad. G. Bonchev Str., Build. 9, 1113 Sofia, Bulgaria \\ ${ }^{b}$ Institute of Chemistry, Faculty of Natural Sciences and Mathematics, \\ Ss. Cyril and Methodius University, Arhimedova 5, 1000 Skopje, P.O. Box 162, Macedonia. \\ ${ }^{c}$ Central Laboratory of Mineralogy and Crystallography, Bulgarian Academy of Sciences, \\ Acad. G. Bonchev Str., Build. 107, 1113 Sofia, Bulgaria \\ E-mail: emilp@pmf.ukim.mk
}

DOI: http://dx.doi.org/10.3998/ark.5550190.0011.a06

\begin{abstract}
4-Aminocoumarin 2 was prepared in high yield via solventless reaction. The structure of the 2 was determined with single crystal X-ray analysis. The detailed NMR and IR spectra were reported for the first time. DFT calculations [B3LYP/6-31+G**] showed good agreement between the theoretical and experimental values for the optimized and X-ray structures, as well as between the vibrational and NMR spectroscopy. The thermodynamic $\mathrm{p} K_{\mathrm{BH}}$ values were calculated using three different methods: Yates and McClelland (with $H_{\mathrm{A}}$ acidity functions), Excess Acidity Method and Bunnett and Olsen Method. The experimental and theoretical data presented are consistent with the weak nucleophilic properties of $\mathbf{2}$.
\end{abstract}

Keywords: 4-Aminocoumarin, crystal structure, spectra, nucleophilic properties

\section{Introduction}

Coumarin and its derivatives from natural products, either semi-synthetic or synthetic, represent one of the most active classes of compounds exhibiting a wide spectrum of biological activity. Additionally, coumarin derivatives are used as additives in food and cosmetic industry. Due to the significance of these compounds, the quest for efficient syntheses of coumarin ring compounds ${ }^{1}$ as well as new bioactive derivatives from known coumarins ${ }^{2}$ is topic.

From the group of aminocoumarins, 3-aminocoumarin and 7-aminocoumarin derivatives are well studied. The 3-aminocoumarin moiety can be recognized in the molecular structure of 
several natural antibiotics, such as novobiocin, chlorobiocin, coumermycin, etc. These antibiotics and their derivatives are in the research focus. ${ }^{3}$ In addition, some simple N-acylderivatives of 3aminocoumarin exhibit an anti-inflammatory activity ${ }^{4}$ and antimicrobial activity against the Gram-positive bacteria. ${ }^{5}$ Most of the publications for 7 -aminocoumarin derivatives present interesting photochemical behavior of these compounds ${ }^{6}$ and many of them can be used as fluorescent markers. ${ }^{7}$ Furthermore, some platinum complexes of 7 -aminocoumarins have been synthesized and evaluated for their in vitro cytotoxicity against Caco-2T cells. ${ }^{8}$ Derivatives of 4aminocoumarin 2 were not studied that much, although some of them possess biological activity as well. ${ }^{9}$

The interesting chemical and physical properties and the pharmacological effects of aminocoumarin derivatives were the main motivation for starting this research. At first, the compound 2 was synthesized as a starting compound for the synthesis of large spectra of new coumarin derivatives. However, during the research we have noticed that the amino group in this compound was very weak nucleophile. In contrast to 3-aminocoumarin, aniline, naphthylamine or similar compounds, which are also weak bases, the amino group of $\mathbf{2}$ did not react with $\mathbf{3}$ (Scheme 1; alkyl halides, acyl halides, acetic anhydride, etc) to obtain 4 (N-substituted derivatives). Considering reactions of $\mathbf{2}$, in few publications only it was presented that instead with nitrogen, electrophiles can form a bond with carbon in position 3 (position C8 in Figure 1). ${ }^{10}$ To our knowledge, in only three references, reactions of nitrogen in 2 were presented, ${ }^{11}$ however, the reported yields of the desired products were very poor. Generally, N-substituted derivatives of $\mathbf{2}$ have been obtained by the reactions of amino compounds with 4chlorocoumarin $^{12,10 \mathrm{a}}$ or 4-hydroxycoumarin $\mathbf{1} .^{13}$

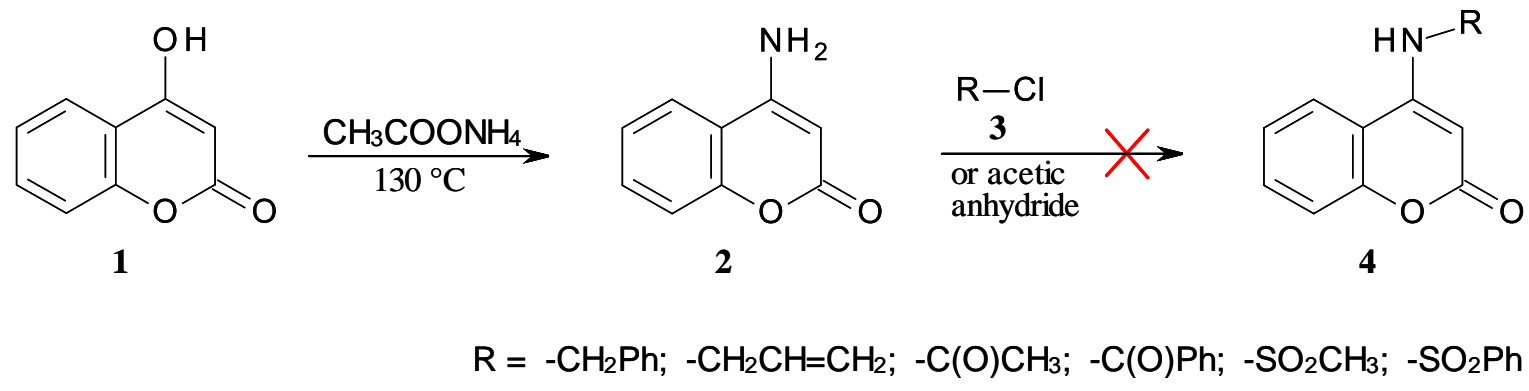

\section{Scheme 1}

Detailed knowledge of the structure and spectral behavior of $\mathbf{2}$ is a necessary prerequisite for understanding its chemical and biological properties. To our surprise, neither NMR nor IR spectra of the title compound have been studied in detail. The purpose of the present study is to elucidate the structure by single crystal X-ray diffraction, UV, NMR and IR spectroscopy. The experimental data will be accompanied by theoretical prediction at different level of approximation in order to draw out the conclusion on the structure-property relationship. 


\section{Results and Discussion}

\section{Synthesis and crystal growth}

Synthesis of $\mathbf{2}$ was performed at $130{ }^{\circ} \mathrm{C}$ via solid state reaction of $\mathbf{1}$ with excess of ammonium acetate (Scheme 1). Excellent pale yellow crystals for X-ray measurement were obtained by slow cooling of ethanol solution of 2 .

\section{Crystal structure}

Molecular structure of compound 2 is shown in Figure 1. The selected bond lengths and angles are given in Table 1.

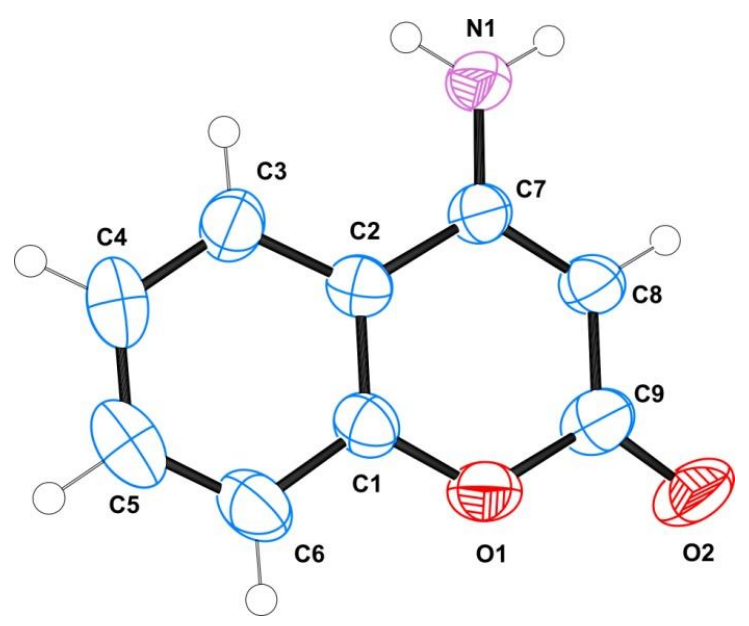

Figure 1. The molecular structure of the title molecule with the atom-numbering scheme; displacement ellipsoids are drawn at the $50 \%$ probability level.

In the molecule of the title compound 2 (Figure 1), the bond lengths and angles are within normal ranges. ${ }^{14}$ The 4-aminocoumarin is almost a planar molecule (rms of $0.0146 \AA$ for the chromene ring). The deviation of planarity is possibly caused by the intermolecular hydrogen bonding, which builds pseudo-layers parallel to $b c$ plane (Table 2, Figure 2). The pseudo-layers are stacked trough $\pi-\pi$ interaction, as evidenced by the distance of ca. $3.48 \AA$ between the chromene ring mean planes.

The C7-N1 bond distance $(1,335 \AA)$ is just somewhat longer then an average $\mathrm{C}=\mathrm{N}$ double bond and little bit shorter then $\mathrm{C} \approx \mathrm{N}$ bond in pyridine $(1,337 \AA),{ }^{15}$ indicating a considerable degree of double bond character. 
Table 1. Selected bond lengths and angles from crystallographic data and comparison with the theoretical data ${ }^{\mathrm{a}}$

\begin{tabular}{|c|c|c|c|}
\hline Parameter & X-ray & B3LYP/6-31+G** & $\mathrm{HF} / 6-31+\mathrm{G}^{* *}$ \\
\hline $\mathrm{C} 2-\mathrm{C} 1$ & $1.386(4)$ & 1.408 & 1.389 \\
\hline $\mathrm{C} 2-\mathrm{C} 3$ & $1.403(4)$ & 1.403 & 1.399 \\
\hline $\mathrm{C} 2-\mathrm{C} 7$ & $1.450(4)$ & 1.460 & 1.466 \\
\hline $\mathrm{O} 1-\mathrm{C} 1$ & $1.374(3)$ & 1.360 & 1.360 \\
\hline $\mathrm{N} 1-\mathrm{C} 7$ & $1.335(3)$ & 1.374 & 1.370 \\
\hline $\mathrm{C} 8-\mathrm{C} 7$ & $1.372(4)$ & 1.370 & 1.347 \\
\hline $\mathrm{C} 8-\mathrm{C} 9$ & $1.399(4)$ & 1.437 & 1.440 \\
\hline $\mathrm{O} 2-\mathrm{C} 9$ & $1.239(3)$ & 1.213 & 1.395 \\
\hline $\mathrm{C} 1-\mathrm{C} 6$ & $1.372(4)$ & 1.399 & 1.390 \\
\hline $\mathrm{C} 3-\mathrm{C} 4$ & $1.368(4)$ & 1.389 & 1.377 \\
\hline $\mathrm{C} 6-\mathrm{C} 5$ & $1.376(4)$ & 1.389 & 1.378 \\
\hline $\mathrm{C} 5-\mathrm{C} 4$ & $1.379(4)$ & 1.403 & 1.399 \\
\hline $\mathrm{C} 1-\mathrm{C} 2-\mathrm{C} 3$ & $117.6(3)$ & 118.1 & 118.3 \\
\hline $\mathrm{C} 1-\mathrm{C} 2-\mathrm{C} 7$ & $118.1(3)$ & 117.2 & 117.0 \\
\hline $\mathrm{C} 3-\mathrm{C} 2-\mathrm{C} 7$ & $124.3(3)$ & 124.6 & 124.7 \\
\hline $\mathrm{C} 1-\mathrm{O} 1-\mathrm{C} 9$ & $120.5(2)$ & 122.1 & 123.2 \\
\hline $\mathrm{C} 7-\mathrm{C} 8-\mathrm{C} 9$ & $122.3(3)$ & 122.9 & 122.2 \\
\hline $\mathrm{C} 6-\mathrm{C} 1-\mathrm{O} 1$ & $115.9(3)$ & 116.5 & 116.6 \\
\hline $\mathrm{C} 6-\mathrm{C} 1-\mathrm{C} 2$ & $122.1(3)$ & 121.1 & 121.3 \\
\hline $\mathrm{O} 1-\mathrm{C} 1-\mathrm{C} 2$ & $122.0(3)$ & 122.4 & 122.1 \\
\hline $\mathrm{O} 2-\mathrm{C} 9-\mathrm{O} 1$ & $113.9(3)$ & 116.9 & 118.0 \\
\hline $\mathrm{O} 2-\mathrm{C} 9-\mathrm{C} 8$ & $127.2(3)$ & 126.8 & 125.5 \\
\hline $\mathrm{O} 1-\mathrm{C} 9-\mathrm{C} 8$ & $118.9(3)$ & 116.2 & 116.5 \\
\hline $\mathrm{C} 4-\mathrm{C} 3-\mathrm{C} 2$ & $120.8(3)$ & 121.1 & 120.9 \\
\hline $\mathrm{N} 1-\mathrm{C} 7-\mathrm{C} 8$ & $121.6(3)$ & 121.8 & 122.3 \\
\hline $\mathrm{N} 1-\mathrm{C} 7-\mathrm{C} 2$ & $120.3(3)$ & 119.2 & 118.8 \\
\hline
\end{tabular}

${ }^{\mathrm{a}}$ For atom numbering see Figure 1.

Table 2. Hydrogen bond geometry for 4-Aminocoumarin

\begin{tabular}{|c|c|c|c|c|}
\hline & $\mathrm{D}-\mathrm{H}[\AA]$ & H...A [Å] & D...A $[\AA]$ & $\mathrm{D}-\mathrm{H} . . . \mathrm{A}\left[{ }^{\circ}\right]$ \\
\hline NHOA...O ${ }^{\mathrm{i}}$ & 0.860 & 2.149 & 2.938 & 152.32 \\
\hline $\mathrm{N}-\mathrm{HOB} \ldots \mathrm{OO} 1^{\text {i i }}$ & 0.860 & 2.103 & 2.925 & 159.75 \\
\hline
\end{tabular}




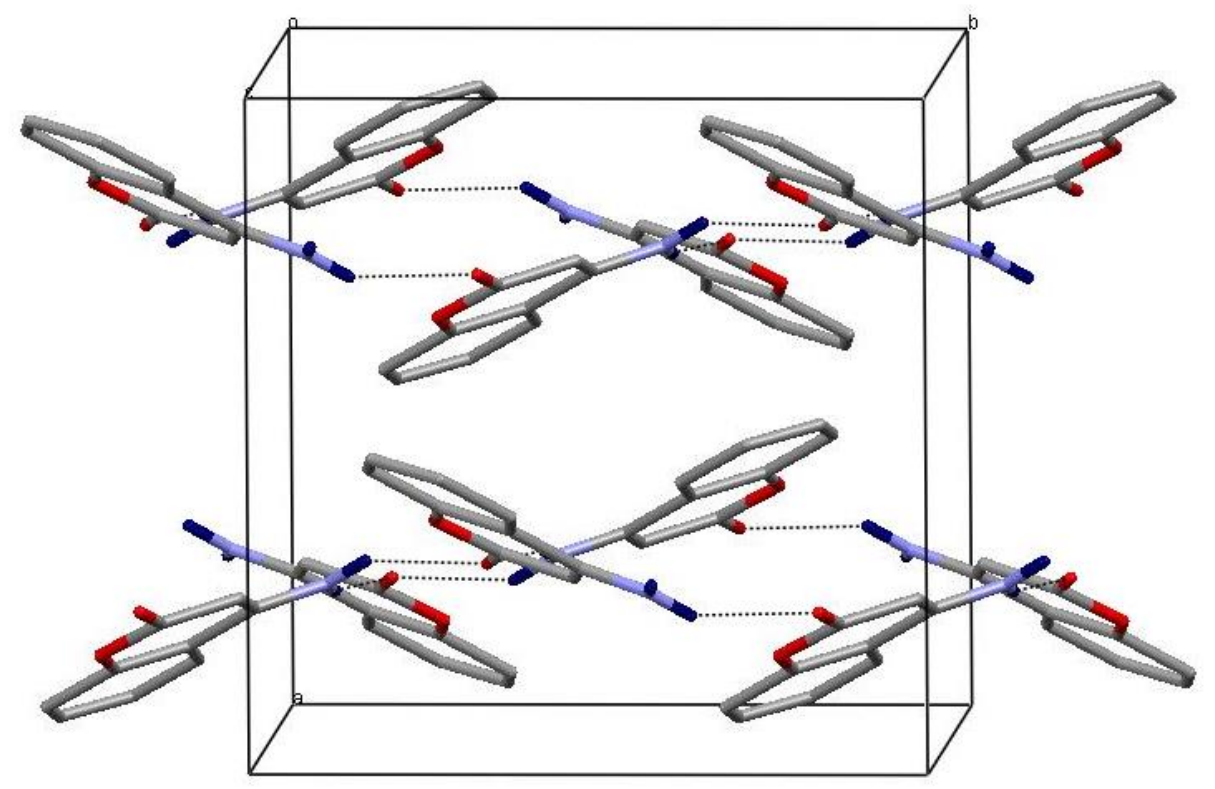

Figure 2. Crystal packing along the $c$ axis showing the propagation of the pseudo-layers propagating parallel to $b c$ plane.

\section{Infrared spectra}

Selected numeric values of measured frequencies together with calculated B3LYP/6-31+G** frequencies and intensities and PED matrix are presented in the Table 3. As one can see, the correlation between experimental and scaled theoretical frequencies is very high. In our study, to determine the types of molecular motion associated with each of the observed experimental bands, the computed vibrational data was used.

The greatest differences between theoretical and experimental IR data correspond to the $\mathrm{NH}_{2}$ stretching vibrations. The calculations predict that the higher-frequency band $\left(3588 \mathrm{~cm}^{-1}\right)$ corresponds to the asymmetric $\mathrm{NH}_{2}$ mode, whereas the other one $\left(3478 \mathrm{~cm}^{-1}\right)$ is assigned to the symmetric one. The measured amino frequencies of 3394 and $3219 \mathrm{~cm}^{-1}$ are significantly lower than theoretically predicted ones, due to the formation of strong hydrogen bonds in solid state. The theory predicted the low intensities of the $v(\mathrm{PhH})$ bands. In solid state IR spectra it is a problem to distinguish these fundamental bands.

With a qualitative agreement between theory and experiment, the $(\mathrm{C}=\mathrm{O})$ band is the strongest one in the spectrum. Experimentally, the very strong band detected at $1634 \mathrm{~cm}^{-1}$, is considerably lower than the value of $1729 \mathrm{~cm}^{-1}$, measured for unsubstituted coumarin. ${ }^{16}$ The lower frequency value is an indication for the occurrence of strong conjugation between the $\mathrm{C}=\mathrm{O}$ and $\mathrm{NH}_{2}$ groups. The normal vibration, dominated by $v(\mathrm{C}-\mathrm{N})$ coordinate was predicted near $1400 \mathrm{~cm}^{-1}$ and measured at $1438 \mathrm{~cm}^{-1}$. For aromatic amines, the frequency of the $v(\mathrm{C}-\mathrm{N})$ band appears at 1360$1250 \mathrm{~cm}^{-1}$ frequency region. The significantly higher frequency in our conjugated molecule is 
another evidence for the occurrence of charge transfer towards the electron withdrawing $\mathrm{CO}$ group.

Table 3. Selected theoretical and experimental vibrational frequencies $\left(v\right.$ in $\left.\mathrm{cm}^{-1}\right)$ and IR integrated intensities (A in $\mathrm{km} \cdot \mathrm{mol}^{-1}$ ) of 4-aminocoumarin

\begin{tabular}{cccc}
\hline$v_{\text {calc. a }}$ & $A_{\text {calc. }}$ & $v_{\text {exp. }}$ & Approximate description ${ }^{\mathrm{b}}$ \\
\hline 3588 & 30.2 & 3394 & $100 v_{N H_{2}}^{a s}$ \\
3478 & 41.9 & 3218 & 100 \\
1737 & 820.2 & 1634 & 83 \\
1615 & 337.7 & 1601 & $45^{\delta_{H N H}, 23}$ \\
1603 & 83.5 & & $35^{v_{C H}^{P h}}, 15^{\delta_{C C C}^{P h}, 12}$ \\
1587 & 3.1 & & $3 v_{C H}^{P h}, 24 \delta_{H N H}, 15^{v_{C C}}$ \\
1545 & 58.8 & 1547 & $41_{C H}^{P h}, 19^{v_{C C}}$ \\
1477 & 26.1 & 1509 & $3 \delta_{C C H}^{P h}, 12^{v_{C C}}$ \\
1430 & 17.9 & 1459 & $35 \delta_{C C H}^{P h}, 23 \delta_{C C C}^{P h}$ \\
1400 & 90.9 & 1438 & $24,16^{P h} \delta_{C C C}, 11$ \\
1326 & 23.3 & 1333 & $7 v^{P h}$ \\
1268 & 1.5 & & $24,22,14 \delta_{C C H}, 12$ \\
1261 & 27.0 & 1266 & $62 \delta_{C C C}^{P h}$ \\
1235 & 46.1 & & $23 \delta_{C C H}^{P h}, 17,14$ \\
1159 & 96.5 & 1196 & $30 \delta_{C C H}^{P h}, 16,16$ \\
1147 & 21.8 & 1120 & $44 \delta_{C C H}^{P h}, 25 v_{C C}^{P h}$ \\
1123 & 6.2 & & $48 \delta_{C C H}^{P h}$ \\
1094 & 36.1 & 1077 & $13 \delta_{C N H}, 11 \delta_{C C H}^{P h}$ \\
\hline
\end{tabular}

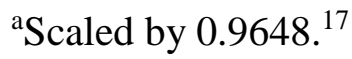

${ }^{\mathrm{b}}$ Vibrational modes: $v$, stretching; $\delta$, in plane and out of plane deformations; $\tau$, torsion; The numbers before the mode symbols indicate $\%$ contribution (10 or more) of a given mode to the corresponding normal vibration, according to the potential energy distribution matrix. ${ }^{18}$

\section{${ }^{1} \mathrm{H}$ and ${ }^{13} \mathrm{C}$ NMR Spectra}

To the best of our knowledge, the full NMR spectra of $\mathbf{2}$ have not been published yet. Therefore, the experimental and calculated ${ }^{1} \mathrm{H}$ and ${ }^{13} \mathrm{C}$ spectra (Table 4) in this paper were included. The 
spectra were assigned with assistance of 1 and 2D (COSY, HMQC and HMBC) NMR spectra. The calculated spectral data were in agreement with the experimental.

Table 4. Calculated $\left(\mathrm{HF} / 6-31+\mathrm{G}^{* *}\right)$ and experimental ${ }^{1} \mathrm{H}(250.13 \mathrm{MHz})$ and ${ }^{13} \mathrm{C}(62.89 \mathrm{MHz})$ NMR spectral data (chemical shifts, ${ }$ in ppm; coupling constants $J$ in Hz)

\begin{tabular}{ccc}
\hline No. $^{a}$ & Calc. & Exp. \\
\hline C1 & 154.0 & 153.7 \\
C2 & 112.6 & 114.5 \\
C3 & 123.9 & 123.0 \\
C4 & 119.3 & 123.3 \\
C5 & 134.7 & 132.1 \\
C6 & 117.0 & 116.8 \\
C7 & 156.4 & 155.7 \\
C8 & 87.0 & 84.0 \\
C9 & 156.2 & 161.8 \\
H3 & 7.91 & 7.98 dd $(8.3,1.2)$ \\
H4 & 7.44 & 7.30 overl. \\
H5 & 7.99 & 7.59 ddd $(8.0,8.0,1.2)$ \\
H6 & 7.25 & 7.28 overl. \\
H8 & 5.24 & $5.21 \mathrm{~s}$ \\
\hline
\end{tabular}

${ }^{a}$ Numbering according to Figure 1.

\section{UV spectra}

The spectra of 4-aminocoumarin in sulfuric acid solutions, reconstructed in the region from 195 to $400 \mathrm{~nm}$ (Figure 3), exhibit four bands resulting from $\pi \rightarrow \pi^{*}$ transitions. With increasing the concentration of the mineral acid, the band with $\lambda_{\max }$ at $209 \mathrm{~nm}$ exhibited small hypsochromic and hypochromic effect, i.e. it shifted towards shorter wavelengths and decreased in intensity (Table 5). The absorption band at approximately $228 \mathrm{~nm}$ in water appeared only as shoulder, while in sulfuric acid solution it exhibited a hyperchromic effect. The absorption band at $250 \mathrm{~nm}$ shifted towards longer wavelengths $(257 \mathrm{~nm})$ and increased in intensity. In the same time, bands at longer wavelengths (291 and $304 \mathrm{~nm}$ in water) showed both hypsochromic and hyperchromic effects. As a result, the absorption band at longer wavelengths could not be clearly recognized, being submerged (hidden) under the high-intensity band with $\lambda_{\max }$ at $287 \mathrm{~nm}$. 


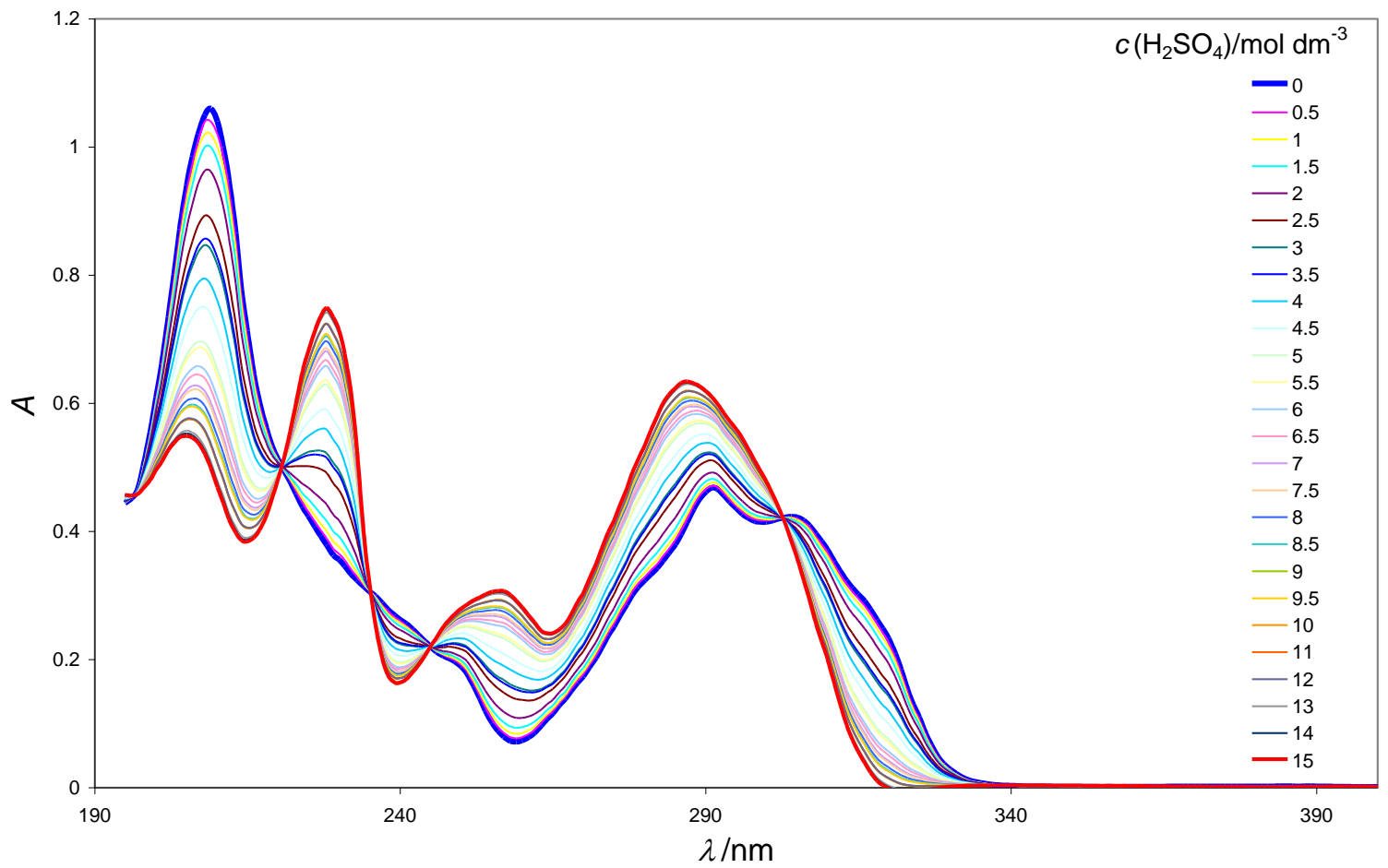

Figure 3. Changes in the reconstructed UV spectra of 4-aminocoumarin as a function of sulfuric acid concentration from 0.0 to $15.0 \mathrm{~mol} \mathrm{dm}^{-3}$

Table 5. Experimental transitions in the UV spectra of unprotonated and protonated form of 4aminocoumarin $\left(c=4.93 \cdot 10^{-5} \mathrm{~mol} \mathrm{dm}{ }^{-3}\right)$

\begin{tabular}{lllllll}
\hline $\mathrm{B}$ & $\lambda_{\max } / \mathrm{nm}$ & 209 & $228(\mathrm{sh})$ & $257(\min )$ & 291 & 304 \\
\cline { 2 - 7 } & $\log \{\varepsilon\}$ & 4.57 & 4.13 & 3.42 & 4.21 & 4.15 \\
$\mathrm{BH}^{+}$ & $\lambda_{\max } / \mathrm{nm}$ & 205 & 228 & 257 & 287 & $304(\mathrm{sh})$ \\
& $\log \{\varepsilon\}$ & 4.07 & 4.21 & 3.84 & 4.15 & 3.90 \\
\hline
\end{tabular}

sh-shoulder, $[\varepsilon]=\mathrm{dm}^{3} \mathrm{~mol}^{-1} \mathrm{~cm}^{-1}$

\section{Determination of $\mathbf{p K}_{\mathrm{BH}}{ }^{+}$}

Acid-base properties of coumarin and its derivatives have been previously studied, but to the best of our knowledge, no protonation data for $\mathbf{2}$ using UV spectroscopy have been published so far. Structures of protonated forms of coumarin and their hydroxy derivatives have been studied by UV and fluorescence spectroscopy. ${ }^{19}$ The acid-base properties of 3-formyl-7dialkylaminocoumarins ${ }^{20}$ and 3-benzazolylcoumarins ${ }^{21}$ have been investigated, too. In order to determine the basicity of $\mathbf{2}$, the thermodynamic $\mathrm{p}_{\mathrm{BH}^{+}}{ }^{+}$values and solvation parameters were calculated using three different methods: Yates and $\mathrm{McClelland}^{22}$ (with $H_{\mathrm{A}}$ acidity functions, where $-H_{\mathrm{A}}=m^{*} \cdot X+\log \left\{\mathrm{CH}^{+}\right\}$), Excess Acidity Method ${ }^{23}$ and Bunnett and Olsen Method. ${ }^{24}$ Ionization ratios were calculated from the absorbances of the free and protonated base in 26 different sulphuric acid solutions at several selected wavelengths. Also, they were obtained 
directly from the coefficients of the first characteristic vector. Characteristic vector analysis was successfully applied to separate the effect of protonation from the medium effect. The first characteristic vector accounts for about $98 \%$ of the variance in the region 195-400 nm.

Protonation parameters (dissociation constant for protonated form of $\mathbf{2}$ and solvation parameters) calculated from absorbances at reconstructed wavelengths and first characteristic vector are presented in Table 6.

The $\mathrm{p} \mathrm{BBH}^{+}$values calculated with all three methods were determined to be between -1.08 and -1.20. Best correlation was obtained using Bunnett and Olsen Method, where average $\mathrm{p} \mathrm{KBH}^{+}$is 1.11. The slope of the $\log I$ vs. $H_{\mathrm{A}}$ (calculated using the $m^{*}=0.3$ ) was close to 1 . The results indicate that the acidity function $H_{\mathrm{A}}$ satisfactorily describes the protonation equilibria for the entire acidity range. The obtained $\phi\left(1-\mathrm{m}^{*}\right)$ values presented in Table 6 were positive, as expected for oxygen Brønsted bases. The site of protonation is probably the carbonyl oxygen, according to the previous theoretical studies of coumarin and derivatives. ${ }^{19}$

Table 6. Protonation parameters for 2 calculated from reconstructed wavelengths and first characteristic vector

\begin{tabular}{ccccccc}
\hline Method & $\begin{array}{c}\text { Protonation } \\
\text { parameters }\end{array}$ & $209 \mathrm{~nm}$ & $228 \mathrm{~nm}$ & $257 \mathrm{~nm}$ & $287 \mathrm{~nm}$ & $\begin{array}{c}\text { characteristic } \\
\text { vector } \mathrm{c}_{1}\end{array}$ \\
\hline & $\mathrm{p} K_{\mathrm{BH}}{ }^{+}$ & $-1.14(0.06)$ & $-1.20(0.06)$ & $-1.20(0.06)$ & $-1.21(0.06)$ & $-1.20(0.06)$ \\
YMC & $m$ & $1.05(0.03)$ & $1.07(0.04)$ & $1.07(0.04)$ & $1.08(0.04)$ & $1.08(0.04)$ \\
$\mathrm{M}$ & $r(\mathrm{n}=24)$ & 0.9888 & 0.9875 & 0.9860 & 0.9870 & 0.9874 \\
& $\mathrm{p} K_{\mathrm{BH}}^{+}$ & $-1.10(0.05)$ & $-1.14(0.05)$ & $-1.14(0.05)$ & $-1.15(0.05)$ & $-1.14(0.05)$ \\
$\mathrm{EAM}$ & $m^{*}$ & $0.31(0.02)$ & $0.32(0.02)$ & $0.32(0.02)$ & $0.32(0.02)$ & $0.32(0.02)$ \\
& $r(\mathrm{n}=24)$ & 0.9688 & 0.9645 & 0.9600 & 0.9622 & 0.9638 \\
& $\mathrm{p} K_{\mathrm{BH}}^{+}$ & $-1.08(0.05)$ & $-1.12(0.06)$ & $-1.12(0.06)$ & $-1.13(0.06)$ & $-1.12(0.06)$ \\
$\mathrm{BOM}$ & $\phi$ & $0.70(0.02)$ & $0.69(0.02)$ & $0.70(0.02)$ & $0.69(0.02)$ & $0.69(0.02)$ \\
& $r(\mathrm{n}=24)$ & 0.9926 & 0.9910 & 0.9904 & 0.9904 & 0.9908 \\
\hline
\end{tabular}

The value of the $\mathrm{p} \mathrm{KBH}^{+}$of 2 was between values of the $\mathrm{p} \mathrm{BBH}^{+}$of benzamide $\left(-1.43^{25}\right)$ and acetamide $\left(-0.66^{26}\right)$, both with very weak nucleophilic properties of $\mathrm{NH}_{2}$ group. 3Aminocoumarin $\left(\mathrm{p} K_{\mathrm{a}}=1.0^{27}\right)$, aniline $\left(\mathrm{p} K_{\mathrm{a}}=4.6^{28}\right)$, 1-naphthylamine $\left(\mathrm{p} K_{\mathrm{a}}=3.9^{29}\right)$ and 2naphthylamine $\left(\mathrm{p} K_{\mathrm{a}}=4.2^{29}\right)$ are weak bases too, but unlike previous compounds they are with positive $\mathrm{p} K_{\mathrm{a}}$ values, have sufficiently nucleophilic properties to react with alkyl halogenides, carboxylic acid anhydrides, acyl halides, sulfonyl chlorides, etc. 


\section{Conclusions}

The structure of $\mathbf{2}$ was determined with single crystal X-ray analysis. The full data from NMR and IR spectra were reported for the first time. The calculated values with quantum chemical methods were in accordance with the experimental. The C7-N1 bond distance indicates a considerable degree of double bond character. The conjugation of $\mathrm{NH}_{2}$ is additionally confirmed by the infrared spectra. This is most probably the reason for very low nucleophility of nitrogen atom in molecule of 2 . Moreover, the values of $\mathrm{pK}_{\mathrm{BH}}{ }^{+}$correlate with the week nucleophilic properties of 2 .

Considering the above mentioned and our experience in performing reactions with $\mathbf{2}$, an attempt to synthesize $\mathrm{N}$-substituted 4 -aminocoumarins from $\mathbf{2}$ would be bad strategy.

\section{Experimental Section}

General. Ammonium acetate and 4-hydroxycoumarin were purchased commercially and used without further purification. Melting points were determined on a Reichert hot-stage apparatus. The crystallographic analysis was carried out on an Enraf-Nonius CAD4 diffractometer, using graphite monochromated Mo-K $\alpha$ radiation $(\lambda=0.71073 \AA)$ at room temperature. An orange irregular block was cut off from a large crystal and selected for measurement of the intensities. Unit cell parameters were determined from centering 22 reflections in the $\theta$ range (17.94-19.58) ${ }^{\circ}$ and refined by the least-squares method. Maximum $2 \theta$ was $27.98^{\circ}$ and scan mode: $\omega / 2 \theta$. Three standard reflections were monitored every 500 reflections during data collection and no significant intensity decay was observed. All diffracted intensities were corrected for Lorentz and polarization effects. ${ }^{30}$ No absorption correction was employed. After merging of equivalent reflections, 1836 independent reflections were obtained $\left(R_{\text {int }}=0.0896\right)$, which were used for the solution and refinement of the structure. The structure was solved by direct methods and was refined by the full-matrix least-squares method using SHELXS97 and SHELXL97 computer programs,${ }^{31}$ respectively, in the space group C $2 / \mathrm{c}$ (no. 15). All non-hydrogen atoms were refined with anisotropic displacement parameters. $\mathrm{H}$ atoms were placed at idealized positions using standard geometric criteria. The final refinement of the structure converged to the final indices $\mathrm{R} 1=0.0578$ and $w \mathrm{R} 2=0.1538$ for 1836 reflections with $[\mathrm{I}>2 \sigma(\mathrm{I})]$. The ORTEP program ${ }^{32}$ was used to generate the ellipsoid plot and the figures involving H-bonds and packing were drawn using Mercury. ${ }^{33}$ Further relevant crystallographic data are summarized in Table 7.

The FTIR spectra $\left(4000-400 \mathrm{~cm}^{-1}\right)$ were recorded at ambient temperature as $\mathrm{KBr}$ pellets on Perkin-Elmer System 2000.

The NMR spectra were run on a Bruker DRX 250 spectrometer using standard Bruker software in solvent DMSO- $\mathrm{d}_{6}$. The residual solvent signal was used as an internal standard for the ${ }^{1} \mathrm{H}(\delta=$ $2.5 \mathrm{ppm})$ and ${ }^{13} \mathrm{C}(\delta=39.5 \mathrm{ppm})$ NMR spectra. 
The UV spectra of the $\mathbf{2}$ (altogether 26 samples) and appropriate blanks were recorded in a range of sulfuric acid solutions from 0.0 to $15.0 \mathrm{~mol} \mathrm{dm}^{-3}$. The UV spectra were recorded, immediately after preparing the solutions, on a Varian Cary 50 Spectrophotometer in $1 \mathrm{~cm}$ quartz cell, with resolution of $1 \mathrm{~nm}$, in the range from 190 to $400 \mathrm{~nm}$, at room temperature. Since the absorption spectra are affected by medium effects (well-defined isosbestic points have not been observed), corrections were made by means of the characteristic vector analysis using the developed procedure in MathCad environment, on preprocessed experimental data (all normalized to unit area under the curves).

Table 7. Crystal data and structure refinement for 4-aminocoumarin

\begin{tabular}{|c|c|}
\hline Crystal formula & $\mathrm{C}_{9} \mathrm{H}_{7} \mathrm{NO}_{2}$ \\
\hline Formula weight & 161.16 \\
\hline Crystal dimensions $(\mathrm{mm})$ & $0.20 \times 0.18 \times 0.14$ \\
\hline Temp $(\mathrm{K})$ & $290(2)$ \\
\hline Crystal system & Monoclinic \\
\hline Space group & $\mathrm{C} 2 / \mathrm{c}$ \\
\hline$a(\AA)$ & $10.830(4)$ \\
\hline$b(\AA ̊)$ & $10.758(4)$ \\
\hline$c(\hat{A})$ & $13.213(5)$ \\
\hline$\alpha\left({ }^{\circ}\right)$ & 90.0 \\
\hline$\beta\left({ }^{\circ}\right)$ & $93.12(2)$ \\
\hline$\gamma\left({ }^{\circ}\right)$ & 90.0 \\
\hline$V\left(\AA^{3}\right)$ & $1537.1(1)$ \\
\hline$Z ; \mathrm{D}_{\text {calc }},\left(\mathrm{g} \mathrm{m}^{-3}\right)$ & $8 ; 1.393$ \\
\hline$F(000)$ & 672 \\
\hline Range of $\theta\left({ }^{\circ}\right)$ & $2.7-27.98$ \\
\hline$\mu(\operatorname{MoK} \alpha)\left(\mathrm{mm}^{-1}\right)$ & 0.10 \\
\hline Reflections collected & 3596 \\
\hline Independent reflections & $1836\left(\mathrm{R}_{\mathrm{int}}=0.0896\right)$ \\
\hline Absorption correction & none \\
\hline $\mathrm{R}\left[\mathrm{F}^{2}>2 \sigma\left(\mathrm{F}^{2}\right)\right] / \mathrm{R} w\left(\mathrm{~F}^{2}\right)$ & $0.0578 / 0.1538$ \\
\hline GOF & 0.94 \\
\hline Final shift & 0.000 \\
\hline$(\Delta \rho)_{\min ,},(\Delta \rho)_{\max },\left(\mathrm{e} \dot{\mathrm{A}}^{-3}\right)$ & $-0.21 / 0.16$ \\
\hline
\end{tabular}

The $a b$ initio restricted Hartree-Fock (RHF) method and DFT are used to obtain equilibrium geometry of 4-aminocoumarin molecule. All calculations have been performed with the standard GAUSSIAN software (AIX, version 1998). ${ }^{34}$ DFT method, employed in the present study is B3LYP-Becke's three parameter hybrid method ${ }^{35}$ using the correlation functional of Lee, Yang and Parr. ${ }^{36}$ The standard $6-31+\mathrm{G}^{* *}$ basis set was applied in all calculations. The local minimum 
was verified by establishing that the matrix of the energy second derivatives (Hessian) has no negative eigenvalues. The theoretical vibrational spectra were interpreted by means of potential energy distributions (PEDs) using VEDA 4 program. ${ }^{18}$ For a better correspondence between experimental and calculated values, we modified the results using the empirical scaling factors. ${ }^{17}$ $1 \mathrm{H}$ and 13C NMR chemical shifts were calculated by using the GIAO method ${ }^{37}$ at the HF/6$311+\mathrm{G}^{* *}$ level of theory (reference compound TMS was calculated at the same level); a solvent was not considered.

4-Aminocoumarin (2). A mixture of well powdered 4-hydroxycoumarin (1,07 g, 0,0066 mol) and ammonium acetate $(7,87 \mathrm{~g}, 0,1 \mathrm{~mol})$ was melted in an oil bath $\left(\max .130^{\circ} \mathrm{C}\right)$. Liquid mixture was stirred 3 hours and was left to cool to ambient temperature. At the cooled mixture, water was added. Crude product (max. $74 \%$ ) was isolated as yellow crystals by simple filtration. First purification was made by dissolving the crystals in ethanol and precipitation with water. Melting point $226-228^{\circ} \mathrm{C}$ (from ethanol). Various melting points were found in the literature, 161.5-162 ${ }^{\circ} \mathrm{C},{ }^{38} 199{ }^{\circ} \mathrm{C},{ }^{13 \mathrm{a}} 232-234{ }^{\circ} \mathrm{C},{ }^{12 \mathrm{a}, 39} 241-243{ }^{\circ} \mathrm{C} .{ }^{40}$ Anal.Calcd. for $\mathrm{C}_{9} \mathrm{H}_{7} \mathrm{NO}_{2}: \mathrm{C}, 67.07 \%$; $\mathrm{H}, 4.38 \%$; $\mathrm{N}, 8.69 \%$. Found: C, 66.94\%; H, 4.61\%; N, 8.61\%.

Reactions of 2 with 3 (Scheme 1) were performed in different solvents $\left(\mathrm{H}_{2} \mathrm{O}\right.$, dioxane, tetrahydrofuran, pyridine, DMSO and DMF), without and with presence of triethylamine, $\mathrm{Na}_{2} \mathrm{CO}_{3}$ or pyridine. Also, same reactions were performed at room temperature and by heating the reaction mixture. In addition, two reactions were performed by refluxing the solution of $\mathbf{2}$ in acetic anhydride or ethyl acetate.

\section{Supplementary material}

CCDC 754032 contains the supplementary crystallographic data for this paper. These data can be obtained free of charge via www.ccdc.cam.ac.uk/conts/retrieving.html (or from the Cambridge Crystallographic Data Centre, 12, Union Road, Cambridge CB2 1EZ, UK; fax: +44 1223 336033).

\section{Acknowledgements}

This work was supported by the Bulgarian National Science Fund (Contract BM-02/07) and Macedonian Ministry of Education and Science (Contract 03-1586). 


\section{References}

1. (a) Mandhane, P. G.; Joshi, R. S.; Ghawalkar, A. R.; Jadhav, G. R.; Gill, C. H. Bull. Korean Chem. Soc. 2009, 30(12), 2969. (b) Matloubi Moghaddam, F.; Mirjafary, Z.; Saeidian, H. Scientica Iranica, Transactions C: Chemistry and Chemical Engineering 2009, 16, 12. (c) Shaabani, A.; Ghadari, R.; Rahmati, A.; Rezayan, A. H. J. Iran. Chem. Soc. 2009, 6, 710. (d) Chavana, F.; Madjea, B.; Bharada, J.; Ubalea, M.; Wareb, M.; Shingareb, M.; Shindec, N. Bulletin of the Ctalysis Society of India 2008, 7, 41. (e) Kumar, S.; Saini, A.; Sandhu, J. S. Arkivoc 2007, (xv), 18. (f) Rajitha, B.; Naveen Kumar, V.; Someshwar, P.; Venu Madhav, J.; Narsimha Reddy, P.; Thirupathi Reddy, Y. Arkivoc 2006, (xii), 23.

2. (a) Naveen Kumar, V.; Thirupathi Reddy, Y.; Narasimhareddy, P.; Rajithaa, B.; De Clercq, E. Arkivoc 2006, (xv), 181. (b) Satyanarayana, V. S. V.; Sreevani, P.; Sivakumar, A.; Vijayakumar, V. Arkivoc 2008, (xvii), 22. (c) Rajendra Prasad, Y.; Ravi Kumar, P.; Jesse Smiles, D.; Ajay Babu, P. Arkivoc 2008, (xi), 266. (d) Kaswala, P. B.; Chikhalia, K. H.; Shah, N. K.; Patel, D. P.; Patel, D. H.; Mudaliar G. V. Arkivoc 2009, (xi), 326. (e) Manojkumar, P.; Kochupappy Ravi, T.; Subbuchettiar, G. Acta Pharm. 2009, 59, 159.

3. (a) Heide, L. Methods Enzymol. 2009, 459, 437. (b) Anderle, C.; Stieger, M.; Burrell, M.; Reinelt, S.; Maxwell, A.; Page, M.; Heide L. Antimicrob. Agents Chemother. 2008, 52,1982. (c) Anderle, C.; Li, S.; Kammerer, B.; Gust, B.; Heide, L. J. Antibiot. 2007, 60, 504. (d) Fridman, M.; Balibar, C. J.; Lupoli, T.; Kahne, D.; Walsh, C. T.; Garneau-Tsodikova S. Biochemistry 2007, 46(28), 8462. (e) Kudale, A. A.; Kendall, J; Warford, C. C.; Wilkins, N. D.; Bodwell, G. J. Tetrahedron Lett. 2007, 48, 5077. (f) Li, S.; Heide, L. Curr. Med. Chem. 2005, 12, 419. (g) Freitag, A.; Galm, U.; Li, S.; Heide, L. J. Antibiot. 2004, 57, 205. (h) Xu, H.; Heide, L.; Li, S. Chem. Biol. 2004, 11, 655.

4. Maddi, V.; Mamledesai, S. N.; Satyanarayana, D.; Swamy, S. Indian J. Pharm. Sci. 2007, 69, 847.

5. Al-Haiza, M. A.; Mostafa, M. S.; El-Kady, M. Y. Scientific Journal of King Faisal University (Basic and Applied Sciences) 2005, 6, 1426.

6. (a) Bhojya Naik, R.; Bhojya Naik, H. S.; Harish Kumar, H. N.; Hosamani, K. M.; Mahadevan, K. M. Arkivoc 2009, (ii), 11. (b) Wagner, B. D. Molecules 2009, 14, 210. (c) Choi, J. Y.; Park, E. J.; Chang, S. H.; Kang, T. J. Bull. Korean Chem. Soc. 2009, 30, 1452.

7. (a) Li, J.; Yao, S. Q. Org. Lett. 2009, 11, 405. (b) Lewis, E. K.; Haaland, W. C.; Nguyen, F.; Heller, D. A.; Allen, M. J.; MacGregor, R. R.; Berger, C. S.; Willingham, B.; Burns, L. A.; Scott, G. B. I.; Kittrell, C.; Johnson, B. R.; Curl, R. F.; Metzker, M. L. PNAS 2005, 102, 5346.

8. Kokotos, G.; Theodorou, V.; TzougrakiDieter, C.; Deforce, L. D.; Van den Eeckhout, E. G. Bioorg. Med. Chem. Lett. 1998, 7, 2165.

9. (a) Di Braccio, M.; Grossi, G.; Roma, G.; Marzano, C.; Bacccichetti, F.; Simonato, M.; Bordin, F. Farmaco 2003, 58, 1083. (b) Roma, G.; Di Braccio, M.; Carrieri, A.; Grossi, G.; Leoncini, G.; Signorello, M. G.; Carotti, A. Biorg. Med. Chem. 2003, 11, 123. (c) El-Saghier, 
A. M. M.; Naili, M. B.; Rammash, B. Kh.; Saleh, N. A.; Kreddanc, K. M. Arkivoc 2007, (xvi), 83.

10. (a) Majumdar, K. C.; Bhattacharyya, T. Tetrahedron Lett. 2001, 42, 4231. (b) Jacquot, Y.; Laios, I.; Cleeren, A.; Nonclercq, D.; Bermont, L.; Refouvelet, B.; Boubekeur, K.; Xicluna, A.; Leclercq, G.; Laurent, G. Biorg. Med. Chem. 2007, 15, 2269. (c) Lai., J.; Kuo, P.; Gau, Y.; Yang, D. Tetrahedron Lett. 2007, 48, 7796. (d) Giraud, A.; Vanelle, P.; Giraud, L. Tetrahedron Lett. 1999, 40, 4321. (e) Papoutsis, I.; Spyroudis, S.; Varvoglis, A.; Callies, J. A.; Zhdankin, V. V. Tetrahedron Lett. 1997, 38, 8401. (f) Ivanov, I. C.; Karagiosov, S. K. Synthesis 1995, 633.

11. (a) Kantlehner, W.; Vettel, M.; Lehmann, H.; Edelmann, K.; Stieglitz, R.; Ivanov, I. C. J. Prakt. Chem. 1998, 340, 408. (b) Shepard, M. S.; Carreira, E. M. Tetrahedron 1997, 53, 16253. (c) Connor, D. T.; Young, P. A.; von Strandimann, M. J. Heterocycl. Chem. 1981, 18, 697.

12. (a) Ivanov, I. C.; Karagiosov, S. K.; Manolov, I. Arch. Pharm. (Weinheim) 1991, 324, 61. (b) Zagorevskii, V. A.; Savellev, V. L.; Meshcheryakova, L. M. Chem. Heterocycl. Comp. 1970, $6,944$.

13. (a) Chavan, A. P. J. Chem. Res. 2006, 179. (b) Stoyanov, E. V.; Ivanov, I. C. Molecules 2004, 9, 627. (c) Liao, Y.; Kuo, P.; Yang, D. Tetrahedron Lett. 2003, 44, 1599.

14. Chopra, D.; Venugopala, K. N.; Rao G. K.; Guru, T. N. Row, Acta Cryst. E. 2007, 63, 2826.

15. Allen, F. H.; Kennard, O.; Watson, D. G.; Brammer, L.; Orpen, A. G. Tables, J. Chem. Soc. Perkin Trans. II 1987, S1.

16. Spectral Database for Organic Compounds, www.aist.go.jp

17. Merrick, J. P.; Moran, D.; Radom, L. J. Phys. Chem. A 2007, 111, 11683.

18. Michal, H. J. Vibrational Energy Distribution Analysis, VEDA 4, Warsaw, 2004.

19. Sokolova, I. V.; Loboda, L. I. Struct. Chem. 1983, 23, 848.

20. Kirpichënok, M. A.; Baukulev, V. M.; Karandashova, L. A.; Grandberg, I. I. J. Chem. Heterocycl. Comp. 1991, 27, 1193.

21. Sizova, Z. A.; Karasev, A. A.; Lukatskaya, L. L.; Rubtsov, M. I.; Doroshenko, A. O. Theor. Exp. Chem. 2002, 38, 168.

22. Yates, K.; McClelland, R. A. J. Am. Chem. Soc. 1967, 89, 2686.

23. Bunnet, J. F.; Olsen, F. P. Can. J. Chem. 1966, 44, 1899.

24. Cox, R. A.; Yates, K. J. Am. Chem. Soc. 1978, 100, 3861.

25. Stojković, G.; Popovski, E.; J. Serb. Chem. Soc. 2006, 71, 1061.

26. Bagno, A.; Lovato, G.; Scorrano, J. Chem. Soc. Perkin Trans. 2 1993, 1091.

27. Subba Rao, R. V.; Krishnamurthy, M.; Dogra, S. K. Journal of Photochemistry, 1986, 34, 55.

28. Bordwell, F. G. Acc. Chem. Res. 1988, 21, 456.

29. Montgomery, J. H. Groundwater Chemicals Desk Reference, 4th Edn.; CRC Press, Taylor \& Francis Group: Boca Raton, 2007; pp 783-785.

30. CAD-4 EXPRESS. Version 5.1/1.2. Enraf Nonius, Delft, the Netherlands.

31. Sheldrick, G. M. Acta Cryst. A. 2008, 64, 112 
32. Farrugia, J. L. J. Appl. Cryst. 1997, 30, 565.

33. Macrae, C. F.; Edgington, P. R.; McCabe, P.; Pidcock, E.; Shields, G. P.; Taylor, R.; Towler, M.; van de Streek, J. J. Appl. Cryst. 2006, 39, 453.

34. Frisch, M. J.; Trucks, G. W.; Schlegel, H. B.; Scuseria, G. E.; Robb, M. A.; Cheeseman, J. R.; Zakrzewski, V. G.; Montgomery, Jr., J. A.; Stratmann, R. E.; Burant, J. C.; Dapprich, S.; Millam, J. M.; Daniels, A. D.; Kudin, K. N.; Strain, M. C.; Farkas, O.; Tomasi, J.; Barone, V.; Cossi, M.; Cammi, R.; Mennucci, B.; Pomelli, C.; Adamo, C.; Clifford, S.; Ochterski, J.; Petersson, G. A.; Ayala, P. Y.; Cui, Q.; Morokuma, K.; Malick, D. K.; Rabuck, A. D.; Raghavachari, K.; Foresman, J. B.; Cioslowski, J.; Ortiz, J. V.; Baboul, A. G.; Stefanov, B. B.; Liu, G.; Liashenko, A.; Piskorz, P.; Komaromi, I.; Gomperts, R.; Martin, R. L.; Fox, D. J.; Keith, T.; Al-Laham, M. A.; Peng, C. Y.; Nanayakkara, A.; Gonzalez, C.; Challacombe, M.; Gill, P. M. W.; Johnson, B.; Chen, W.; Wong, M. W.; Andres, J. L.; Head-Gordon, M.; Replogle, E. S.; Pople, J. A. Gaussian 98, Revision A.7, Gaussian, Inc., Pittsburgh PA, 1998.

35. Becke, A. D. Phys. Rev. A 1988, 38, 3098.

36. Lee, C.; Yang, W.; Parr, R. G. Phys. Rev. B 1988, 37, 785.

37. Ditchfield, R. Mol. Phys. 1974, 27, 789.

38. Zagorevskii, V. A.; Dudykina, N. V. Zh. Obsch. Khim. 1962, 32, 2384.

39. Manolov, I.; Danchev, N. D. Eur. J. Med. Chen. Chim. Ther. 1995, 30, 531.

40. Uno, H.; Kurokawa, M.; Nishimura, H. Chem. Pharm. Bull. 1976, $24,644$. 